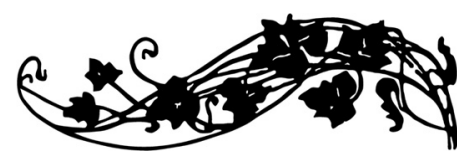

https://doi.org/10.31261/CHOWANNA.2020.54.02

\title{
Michał Kruszelnicki
}

Dolnośląska Szkoła Wyższa

(D) https://orcid.org/0000-0002-4987-9218

\section{Krytyka, opór, nadzieja Wokół publicystyki zaangażowanej Henry’ego A. Giroux}

\author{
Critique, Resistance, Hope: \\ On Henry A. Giroux's Political Journalism
}

\begin{abstract}
The article discusses and problematizes Henry Giroux's postulate to construe academic teachers as public and transformative intellectuals along with his claim that both humanities and social sciences, notably pedagogy, ought to be thought of as politically engaged. The author of the article indicates different factors thwarting the implementation of those postulates, such as: the dominance of neoliberal ideology, the onslaught of market fundamentalism, and an unselective manner in which students are enrolled into universities, in particular humanities' departments. Following in Giroux's footsteps, the author underscores the role played by the discourse of possibility and hope, as a necessary complement to the criticism conceived of as stripping away the "false consciousness," yet - at the same time - he steers clear of the over-optimistic belief espoused by Giroux about the contemporary young people's critical potential and civic agency, as well as the feasibility of reclaiming power over the conditions of their work by academicians.
\end{abstract}

Keywords: Henry Giroux, critique, resistance, neoliberalism, academic teachers, hope

„Co dzieje się z demokracją, gdy prezydent Stanów Zjednoczonych określa krytyczne media mianem »wrogów ludu«?”, „Co dzieje się z demokracją, gdy jednostki lub całe grupy są demonizowane ze względu na 
swoją religię?”, „Co dzieje się z państwem, kiedy wiodącymi zasadami jego społeczeństwa jest przemoc i ciemnota?”, „Co dzieje się ze społeczeństwem, gdy myślenie krytyczne staje się obiektem pogardy?"1 pyta Henry A. Giroux, a my z miejsca myślimy - nie możemy nie myśleć - o naszym kraju. Czym jest owo „krytyczne myślenie”? Wydaje się, że wiemy. Tak wiele wszak o nim napisano, tyle podano jego definicji. Pytanie jednak brzmi: kto, jak i gdzie faktycznie uczy krytycznego myślenia?

W odpowiedzi wskazywany jest uniwersytet jako instytucja, zwłaszcza nauki humanistyczne. Zarazem jednak wielu badaczy obserwuje, że „dzisiejszą kondycję uniwersytetu można opisać najkrócej jako kapitulację wobec zadań wyznaczonych na progu nowoczesności. Uniwersytety utraciły swą funkcję krytyczną i przekształcają się w szkoły wyższe wytwarzające pracowników na potrzeby rynku pracy"2.

Henry Giroux wraz z innymi radykalnymi krytykami kultury piętnuje paraliżujący znaczną część elity intelektualnej mit naukowca jako jednostki wycofanej ze świata, ogarniającej go być może i krytycznym, nawet pogardliwym, wglądem, ale zdystansowanej w obawie przed zbrukaniem swojej pięknej duszy brudem codziennej rzeczywistości. Giroux ostro krytykuje taki eskapizm i promuje wzór naukowca zdolnego do kształtowania opinii publicznej nawet wbrew panującym sądom i władzy. Kwestia zaangażowania nauczycieli akademickich jako "publicznych intelektualistów" stale przewija się w pracach amerykańskiego pedagoga. Jakże trudne stawia on przed nami wyzwanie.

Zadanie stawiane przez Giroux przed naukowcami jest trudne do wykonania z wielu powodów i, rzecz jasna, nie wszystkie można omówić w tekście, który ma formę eseju wprowadzającego w problematykę niniejszego tomu „Chowanny”. Giroux podnosi głównie kwestię wpływu ideologii neoliberalnej na sferę społeczną i polityczną, ofensywy rynkowego fundamentalizmu oraz słabnięcia demokracji w obliczu globalnej tyranii kasynokapitalizmu wspieranego przez autorytarną władzę. Można jednak wskazać kilka innych mechanizmów rzeczywistości, których wpływowy analityk kultury nie tyle nie dostrzega, ile może nie chce dostrzec w swoistej dlań, i nie w całości tu podzielanej, optymistycznej wierze w krytyczny potencjał i obywatelską

${ }^{1}$ H.A. Giroux: Thinking Dangerously: The Role of Higher Education in Authoritarian Times. Truthout. 26.06.2017. [Online:] https://truthout.org/articles/ thinking-dangerously-the-role-of-higher-education-in-authoritarian-times/ [8.06.2020]. Jeżeli nie zaznaczono inaczej, tłumaczenia cytowanych fragmentów - M.K.

${ }^{2}$ M. Gdula: Władza krytyczna i siła wyobraźni. W: Uniwersytet zaangażowany. Przewodnik Krytyki Politycznej. Warszawa 2010, s. 221. 
sprawczość młodych ludzi oraz możliwość przejęcia przez nauczycieli akademickich kontroli nad warunkami własnej pracy.

Giroux stoi na coraz bardziej dziś problematycznym stanowisku, że dostęp do kształcenia wyższego powinien być prawem powszechnym, a nie przywilejem dla wybranych, ale niewystarczająco bierze pod uwagę fakt, iż dzisiejsza rzeczywistość - chęć praktycznego i nastawionego na materialny zysk zarządzania sobą, hiperkonsumpcjonizm i wirtualna rozrywka - wytwarza nowy typ odbiorców edukacji, którym coraz bardziej obce jest syntetyczne myślenie, dostrzeganie nieoczywistych zależności między zjawiskami i wyciąganie pogłębionych wniosków. Odbiorcy ci, mało zorientowani w krajowych i globalnych problemach społeczno-politycznych, często mający rudymentarne braki w wykształceniu średnim, a wręcz podstawowym, już na etapie szkolnym zniechęceni do wyrażania własnych sądów, wytresowani do odtwórczego, pasywnego i konformistycznego stylu uczenia się, o wyobraźni i empatii mocno stępionych przez medialną propagandę oraz stałą ekspozycję na obrazkowe przekazy kultury spektaklu, nie są w stanie wyjść w refleksji i rozumowaniu poza horyzont zwykłego common sense i idiosynkratycznych, drążących tylko lokalnie, zatem powierzchownych wglądów. Poruszanie z takimi odbiorcami newralgicznych kwestii społecznych zawsze oznacza stąpanie po kruchym lodzie i grozi wykładowcy zarzutem „obrazy uczuć religijnych” czy „prezentowania własnych poglądów politycznych", tym samym zaś niesie ryzyko otrzymania złych opinii w ewaluacjach albo bycia przedmiotem skargi do przełożonych. Budowany latami autorytet i wiarygodność wykładowcy można obecnie w jednej chwili podważyć, by dogodzić studentom, dotkniętym alergią na wszelkie treści, których nie sposób bezkrytycznie zakuć, gdyż wymagają wrażliwości i wyobraźni, merytorycznego i logicznego argumentowania swojego stanowiska.

Zasada autonomii w doborze treści kształcenia stała się w ten sposób fikcją. W kryzysie są kierunki humanistyczne, przegrywające nierówną walkę z cyniczną narracją o kształceniu pojętym jako wyposażanie uczniów w kompetencje przydatne na rynku pracy. To takich zajęć domaga się dziś od uniwersytetu wielu kandydatów na studia. Zamiast wykorzystać niż demograficzny jako szansę, by zerwać z utrzymywaniem pozorantów po obu stronach katedr akademickich, uczelnie humanistyczne przyjmują wszystkich chętnych, „oby tylko umieli się podpisać". Wśród tych w żaden sposób nieselekcjonowanych konsumentów wyższej humanistycznej wiedzy znajdują się tacy, którym świat idei i dziedzictwa symbolicznego jest zwyczajnie obcy, otrzymują więc najniższe noty i nierzadko przelewają później swoje frustracje na wykładowców, którzy bronią poziomu i nie obniżają wymagań do minimum w rozpaczliwej i podszytej lękiem próbie utrzymania pracy. 
Co symptomatyczne, wiele uczelni nie tylko przyklasnęło nowym procedurom kontroli, lecz także ochoczo przystąpiło do nadzwyczajnego uszczegóławiania ankiet ewaluacyjnych, co z pewnością uatrakcyjni wysiłek ich wypełniania dla tych studentów, którzy co prawda nie radzą sobie z nauką, za to bez problemu odpowiedzą na pytanie, czy poleciliby zajęcia innym studentom. Tak jak „opiniuje się" i „lajkuje” filmiki i obrazki w Internecie, tak samo można polecić zajęcia na danej uczelni lub ich nie polecić.

Giroux wielokrotnie mówi o narastającej liczbie jednostek i grup, które kapitalizm czyni zbędnymi, jednorazowymi, disposable, skazanymi na śmierć społeczną ${ }^{3}$. Zwróćmy jednak uwagę, że zbędnych produkuje też dzisiejszy uniwersytet. Czyż władzom uczelni, zwłaszcza tych niepublicznych, nie opłaca się bardziej zatrudnianie pracowników na krótkotrwałych kontraktach, zamiast na dających rudymentarne poczucie zakorzenienia i bezpieczeństwa socjalnego etatach? Czyż obecnie pożądanym typem nauczyciela akademickiego nie staje się w pełni przewidywalny, pracujący punktualnie od-do, posiadający rozpisany w punktach sylabus, oferujący przydatne zawodowo umiejętności instruktor - perfekcyjnie „audytowalny” dostarczyciel edukacyjnej usługi? Wyprodukowała go neoliberalna pedagogia głupoty, która ponad fundamentalne i bynajmniej nie neutralne pytania: „czemu edukacja ma służyć?”, „jaki rodzaj podmiotowości, jakie społeczeństwo, jaką przyszłość chcemy tworzyć?", przedkłada kalkulowanie publikacyjnych „punktów” i opracowywanie „obiektywnych” standardów osiągania przez studentów z góry założonych „efektów kształcenia”. Jak wobec tych tendencji domagać się od młodych ludzi bycia krytycznymi myślicielami, a od wykładowców ideologicznego zaangażowania w roli public and transformative intellectuals?

W obliczu kapitalistycznej kolonizacji świata życia, postępującego uzawodowienia edukacji wyższej i prekaryzacji pracy, wraz z zanikaniem wolności nauczycieli akademickich, którzy z co prawda spauperyzowanej, lecz przynajmniej objętej wysokim społecznym zaufaniem grupy zawodowej stali się poddanymi permanentnej kontroli i ewaluacji sługami swoich „klientów”, nie dziwi obawa lub przynajmniej daleko posunięta powściągliwość przed zaangażowaniem, przed podnoszeniem na zajęciach, a także w pisanych tekstach kwestii społecznych i politycznych. Tym samym nauka krytycznego myślenia staje się wypranym z wszelkiej treści postulatem, rutynowo zamieszczanym w kartach przedmiotów bez większego przełożenia na ukazywanie jej

${ }^{3}$ H.A. Giroux: The Vital Role of Education in Authoritarian Times. Truthout. 11.10.2017. [Online:] https://truthout.org/articles/the-vital-role-of-education -in-a-time-of-tyranny/ [8.06.2020]. 
działania w praktyce. Przelęknionym o możliwość utraty jedynej pracy, jaką umieją dobrze wykonywać, i w lęku tym znajdującym usprawiedliwienie swojego defetyzmu akademikom pozostaje karmienie siebie i innych fikcją, że ich przedmiot nauczy krytycznego myślenia samą tylko mocą eksponowania studentów na treści wielkich dzieł z mniej lub bardziej odległej przeszłości.

To jednak tak nie działa. Zdaniem Henry'ego Giroux, trzeba przezwyciężyć wciąż pokutujące mniemanie, że edukacja humanistyczna, zwłaszcza na szczeblu wyższym, musi być odseparowana od polityczności, neutralna i „niewinna”. Jeśli jest neutralna, to znaczy, że jest niezaangażowana, czyli tak czy inaczej działa na rzecz status quo. Postępujący na naszych oczach proces wyłączania kolejnych dóbr publicznych spod opieki państwa i podporządkowywania ich prawom rynku oznacza dla uniwersytetu albo śmierć, albo konieczność funkcjonowania na zasadach przedsiębiorstwa usługowo-produkcyjnego, generującego zyski. Jednocześnie jednak ów kryzys legitymizacji otwiera przed humanistami drogę do przemyślenia istotnego zadania, jakie mogą, muszą oni pełnić w społeczeństwie demokratycznym. I to jest druga, bodaj ważniejsza przesłanka dla domagania się porzucenia spekulatywno-kontemplacyjnego modelu zajmowania się humanistyką. Humanistyka nie tyle bowiem nigdy nie była niewinna - zawsze wszak funkcjonowała $\mathrm{w}$ relacjach władzy i kreowała zbieżne lub właśnie niezbieżne z jej imperatywami wizje rzeczywistości i ludzkiej podmiotowości - ile wręcz nie powinna takiej niewinności się domagać. Ma kluczowe znaczenie polityczne, pozostając sferą absolutnej wolności w doborze i zmianie języków opisu rzeczywistości. Dzięki temu pozwala uświadamiać względność naszego oglądu świata, a zarazem krytykować każdy język znieruchomiały, autarkiczny, pozostający zawsze we własnych tylko granicach, przy czym zawzięcie domagający się wyłączności. Na tym polega, według Michała Pawła Markowskiego, pierwszorzędne znaczenie polityczne humanistyki, jak również rola, jaką może ona odgrywać w przestrzeni publicznej - jako narzędzie kwestionowania wszelkich instytucjonalnych reguł i ideologii, próbujących raz i na zawsze ustalić, co to znaczy być człowiekiem i zajmować się człowiekiem. Autora Polityki wrażliwości najbardziej niepokoi przedziwna pewność niektórych badaczy i funkcjonariuszy akademii w kwestii tego, „co jest, a co nie jest przedmiotem humanistyki”, pewność ta podważa bowiem „prawo do powiedzenia wszystkiego”, które Jacques Derrida przypisuje instytucji literatury oraz naukom humanistycznym i „uniwersytetowi bezwarunkowemu”, czyli takiemu, który nie poddaje się presji żadnych zewnętrznych sił i nacisków. „Móc powiedzieć wszystko to móc wszystko zakwestionować, postawić pod znakiem zapytania, sproblematyzować, niczego nie pozostawić poza 
obszarem refleksji, ale także nie obawiać się, że z powodu korzystania z tego przywileju można na siebie ściągnąć jakiekolwiek niedogodności" ${ }^{4}$ Inna sprawa, że Markowski zdradza nadmierny może optymizm, gdy przemilcza opinię Derridy z tego samego eseju, w myśl której „właśnie dlatego, że ufundowany został, w przeciwieństwie do innych ośrodków badawczych, na zasadzie wolności i niezależności, uniwersytet pozostaje wystawioną na atak, osamotnioną cytadelą, której przeznaczeniem jest bezwarunkowo skapitulować"s.

Giroux nieustannie powtarza, że „rozpoznanie nieodłącznego związku między nauczaniem a polityką jest kluczowe dla odzyskania edukacji wyższej jako demokratycznej sfery publicznej", i nie przestaje mobilizować nauczycieli do krytycznego wypowiadania się o rzeczywistości - piętnowania, odsłaniania, uświadamiania. Jest to zadanie tym pilniejsze, że neoliberalizm już spowodował i ciągle pogłębia potworny „kryzys sprawstwa, reprezentacji, oporu i języka”. Dlatego pedagog domaga się poszukiwania języka, który „byłby polityczny, nie będąc dogmatycznym", języka zaangażowanego, który zrywałby $\mathrm{z}$ abstrakcyjnym i ezoterycznym dyskursem odciętego od sfery praxis uczonego-specjalisty jako „werbalnym kamuflażem, wznoszącym barierę między uniwersytetami a ich publiczną misją" . Język, o jakim mowa, potrafiłby sięgać nawet do dosadnych wyrażeń i nie unikał wrażliwego odsłaniania się w subiektywizmie i emocjach, jeśli tylko na tej drodze można przedrzeć się poza akademicką political correctness, która za fasadą słów o nobliwej instytucji i etosie zawodu skrywa zwykłe tchórzostwo, rejteradę w obliczu oczekiwań studentów i władz, ostatecznie zaś zimną obojętność wobec tego, co jest. Takim właśnie "językiem oburzenia” ${ }^{10}$ trzeba, według Giroux, mówić „wszystko”, by

${ }^{4}$ M.P. Markowski: Polityka wrażliwości. Wprowadzenie do humanistyki. Warszawa 2013 , s. 85.

${ }^{5}$ J. Derrida: L'université sans condition. Paris 2001, s. 18-19.

${ }^{6}$ H.A. Giroux, S.S. Giroux: Take Back Higher Education. Race, Youth, and the Crisis of Democracy in the Post-Civil Rights Era. New York-Houndmills 2004, s. 8.

${ }^{7}$ H.A. Giroux: Teachers Are Rising Up to Resist Neoliberal Attacks on Education. Truthout. 22.01.2019. [Online:] https://truthout.org/articles/teachersare-rising-up-to-resist-neoliberal-attacks-on-education/ [8.06.2020].

${ }^{8}$ H.A. Giroux: The Curse of Totalitarianism and the Challenge of Critical Pedagogy. Truthout. 2.10.2015. [Online:] https://truthout.org/articles/the-curse-oftotalitarianism-and-the-challenge-of-critical-pedagogy/ [8.06.2020].

${ }^{9}$ H.A. Giroux: Teachers Are Rising Up to Resist Neoliberal Attacks on Education...

${ }^{10}$ H.A. Giroux: Where Is the Outrage? Critical Pedagogy in Dark Times. A public lecture on Thursday, September 24th, 2015. YouTube. 22.10.2015. [Online:] https://www.youtube.com/watch?v=CAxj87RRtsc [8.06.2020]. 
pobudzać zdolność wyobrażania sobie innej rzeczywistości, wyrywać studentów z indyferencji i złudnego poczucia komfortu w zastanym porządku.

Zapytajmy jednak, czy postulat ścisłego powiązania edukacji humanistycznej z politycznością da się uzgodnić z przywołaną za Markowskim Derridiańską wizją humanistyki jako sfery absolutnej wolności w wyborze języka opisu rzeczywistości. Czy nakazywanie humanistom posługiwania się pewnym określonym (politycznie zaangażowanym) językiem i stawianie przed nimi jednego konkretnego celu nie stanowi zamachu na ową wolność, nawet jeśli cel ów jest doniosły? $\mathrm{Z}$ pewnością tak. Na taki zarzut Giroux odpowiedziałby jednak, że jest już po prostu za późno - a zagrożenia stojące przed zachodnimi demokracjami zbyt poważne - by przestrzeń humanistyki traktować niczym muzeum. Jej dziedzictwu grozi straszna niemota, jeśli nie wykorzysta się go do refleksji nad losem świata tu i teraz. Przed współczesnym nauczycielem wyrasta tedy zadanie "przerzucania mostów między uczeniem się a życiem codziennym”, łączenia „reading the word with reading the world"11. Niestety, łatwiej dostrzec to, co nauczyciel ma przy tym do stracenia, niż to, co może wygrać. Prawdopodobnie ryzykuje w ten sposób nawet więcej, niż gdy uczy tylko „abstrakcyjnych”, „starodawnych” i „niezwiązanych z praktyką” treści. W mrocznych czasach cynizmu i "niemądrości”, zorientowanej „nie na zmianę świata, lecz coraz dokładniejsze dostosowywanie się do jego wymogów"12, łatwo poddać się desperacji.

Przygotowując grunt pod wprowadzenie kluczowego dla swojego pedagogicznego projektu pojęcia "nadzieja”, Giroux - w ewidentnym nawiązaniu do myśli Petera Sloterdijka ${ }^{13}$ - argumentuje, iż w pełni uwolniona krytyka to nie wszystko, tym bardziej że „prowadzić może do paraliżującej rozpaczy lub nawet gorzej - do groźnego cynizmu"14. To trop dobrze znany z filozoficznych debat nad statusem kultury i podmiotu po inwazji ultrakrytycznych, inspirowanych zwłaszcza myślą Marksa i Nietzschego, dyskursów poststrukturalizmu i dekonstrukcji. Należy jednak podążać tą drogą bardzo ostrożnie. Wśród polskich filozofów edukacji czyni tak Piotr Zamojski, który upomina się o „ponowne przemyślenie roli krytyki w pedagogice”. Przed pedagogiką stawia za-

\footnotetext{
${ }^{11}$ H.A. Giroux: The Curse of Totalitarianism and the Challenge of Critical Pedagogy...

${ }_{12}$ T. Sławek: NICowanie świata. Zdania z Szekspira. Katowice 2012, s. 192, 195 cyt. za: K. Maliszewski: Wióry... Szkic (krypto)terapeutyczny o edukacji wobec zmian współczesnych. „Forum Oświatowe” 2018, nr 1, s. 92.

${ }^{13}$ P. Sloterdijk: Krytyka cynicznego rozumu. Przeł. P. Dehnel. Wrocław 2008.

${ }^{14}$ H.A. Giroux: Thinking Dangerously...
} 
danie „przyswojenia sobie jej [krytyki - M.K.] wewnętrznej struktury normatywnej i wyniesienia tego, czemu krytyka mówi »tak«, do rangi prawdy wydarzającej się w działaniu"15. Edukacja jest nadzieją i musi opierać się na nadziei - powiada - na uwypuklaniu w świecie tego, co dobre i warte zabiegów, nie zaś na krytyce, pesymizmie i cynizmie. Zgoda. Ale czy zasadne jest ogłaszanie - jak to czyni gdański badacz aż „zmierzchu paradygmatu krytycznego" w studiach edukacyjnych? ${ }^{16}$ I to gdzie? W Polsce? W kraju, w którym, po pierwsze, przeciętny pedagog doprawdy niewiele wie o sporze między teorią krytyczną, hermeneutyką a francuskim poststrukturalizmem o status i rolę krytyki, a po drugie, sama możliwość owej krytyki jest permanentnie zagrożona między innymi przez konformistyczną, kapitulującą przed wymaganiami rynku i władzy politykę tej samej instytucji, która tradycyjnie deklarowała się ostoją niezależnego, odważnego myślenia? Niezmitygowany radykalny krytycyzm nie jest, wbrew pozorom, żadną oczywistością ani naturalnym imperatywem stawianym przed edukacją wyższą. Tak bywa tylko w książkach światłych myślicieli i publicystów. O tym, jak jest naprawdę, nierzadko dowiadujemy się z rozmów na dywaniku u naszych przełożonych czy w chwilach, gdy władze pewnej uczelni zakazują opublikowania listu poparcia jej pracowników dla strajkujących nauczycieli, podając jako argument, że "gest zajęcia stanowiska po którejś stronie sporu politycznego niesie ryzyko zmniejszenia naboru kandydatów na studia"...

Autor Take Back Higher Education zawsze pokładał ufność w krytyczności i obywatelskiej sprawczości młodzieży. „Młodzi ludzie mają dużo władzy” - pisał. - „Mogą obalić całe społeczeństwa. Stanowią poważną siłę polityczną i muszą zdać sobie z tego sprawę"17. Istnieją jednak powody, by wątpić, że współczesna młodzież rzeczywiście stanowi niezawodne tworzywo rozwijania żywo debatującej, krytycznej

${ }^{15}$ P. Zamojski: Od demaskacji ku budowaniu. Po-krytyczna perspektywa badań pedagogicznych. „Teraźniejszość - Człowiek - Edukacja” 2014, nr 3, s. 7-22. Por. również: Manifesto for a Post-Critical Pedagogy. Eds. P. Zamojski, N. Hodgson, J. Vlieghe. New York 2018, s. 2, 18-19.

${ }^{16}$ P. Zamojski: Od demaskacji ku budowaniu..., s. 9.

${ }^{17}$ J. França: Henry Giroux: "Those Arguing that Education Should Be Neutral Are Really Arguing for a Version of Education in Which Nobody Is Accountable". An interview with founder of critical pedagogy Henry Giroux on the meaning of education, suspicions regarding neutrality and on how current uncertainties could be a driving force to rethink and generate new possibilities. CCCB [Centre de Cultura Contemporània de Barcelona]. 2.07.2019. [Online:] http://lab.cccb. org/en/henry-giroux-those-arguing-that-education-should-be-neutral-are -really-arguing-for-a-version-of-education-in-which-nobody-is-accountable/ [8.06.2020]. 
i gotowej aktywnie działać sfery publicznej, skoro zamiast poczuciem odpowiedzialności za wspólnotę młodzi ludzie przesiąkają charakterystycznym dla diagnozowanego jeszcze przez Ortegę człowieka masowego poczuciem komfortowej oczywistości i nieproblematyczności świata za oknem oraz neoliberalnymi wartościami prymitywnego utylitaryzmu, hedonizmu i egoizmu. Aby jeszcze bardziej przyciemnić, przeciwko optymizmowi Giroux, obraz rysowanej sytuacji, można sparafrazować Nietzschego i dodać, że do rozbudowy w pełni krytycznego społeczeństwa brakuje nam przede wszystkim „materiału”. Profesor Maria Janion, zapytana, jak się czuje jako wieloletnia nauczycielka, gdy widzi, że uniwersytet, niegdyś zaangażowany i dyskutujący, tworzący warunki dla zaistnienia formacyjnego dla całych pokoleń badaczy seminarium, teraz jest już tylko „neutralną szkołą, politechniką współczesnej gospodarki rynkowej”, odpowiedziała, że „całe [jej M.K.] edukacyjne nastawienie wynikało z przekonania o wrodzonej wrażliwości i otwartości każdego człowieka"18. Nawet przy uwzględnieniu wieku wielkiej Uczonej, która już wówczas musiała już wycofać się z dydaktyki, narzuca się obserwacja, że gdy Janion mówi o swoich wybitnych studentach i uniwersytecie, sięga w odległą już przeszłość. Ciężko nie uniknąć pesymistycznej konstatacji, że młodzi ludzie muszą być dziś bardziej przejęci sobą i własnym przetrwaniem w nieprzychylnym dla nich świecie niż jego zmianą i naprawą. Czy mamy prawo ich winić? Tymczasem Henry Giroux rozpaczliwie pyta: „Where is the outrage?"'19. No właśnie... nie ma. Nie u młodych.

$\mathrm{Z}$ tych i wielu innych względów, o jakich $\mathrm{z}$ braku miejsca nie mogło tu być mowy, obok krytyki potrzebny jest dyskurs nadziei i możliwości, który - jak mówi Giroux - polega na „wierze, nawet w czasach pesymizmu, w możliwość niespodzianki"20. My ujmijmy rzecz inaczej: nadzieja to jedyne, co nam pozostało. $Z$ Europy i Polski dociera wiele sygnałów oporu i niezgody na kierunek „reform”; głosy te świadczą o woli obrony wartości kształcenia humanistycznego w odcięciu od dezyderatów wypracowanych przez urzędników w ramach pozademokratycznie przyjętej strategii bolońskiej. Władza tej czy innej partii, która elementem swej polityki uczyniła manifestowanie pogardy dla tradycyjnego etosu prawdziwych elit intelektualnych, nie będzie trwała wiecznie. Na uczelniach nie wszyscy jeszcze pracownicy stali się służbistami i buchalterami. Trzeba mieć nadzieję, że wśród

${ }^{18}$ M. Janion: Studenci to nie jest niższy personel. Z prof. Maria Janion rozmawiaja Kazimiera Szczuka i Sławomir Sierakowski. W: Uniwersytet zaangażowany. Przewodnik Krytyki Politycznej..., s. 99.

${ }^{19}$ H.A. Giroux: Where Is the Outrage?...

${ }^{20}$ H.A. Giroux: Thinking Dangerously... 
przedstawicieli władz uniwersyteckich, nie tylko uczelni z czołówki krajowego rankingu, znajdą się jednostki, które pomyślą o wdrożeniu mechanizmów doceniania i chronienia odważnych, uczących realnych krytycznych kompetencji nauczycieli, o których „przydatności” nie świadczyłyby ankiety wypełniane przez bardzo różnych studentów, lecz opinia środowiska prawdziwych autorytetów i fachowców, mających wgląd w dorobek naukowy i postawę dydaktyczną wykładowcy. $\mathrm{Na}$ zajęciach zdarzają się osoby autentycznie przeżywające treści humanistyczne i to dla nich chce się te zajęcia prowadzić. Warto zatem tworzyć elitarne kursy dla takich właśnie, gotowych do znacznego wysiłku samokształceniowego, najzdolniejszych studentów; na takich kursach bez obaw, kompleksów i neurozy wcielana w życie byłaby edukacyjna zasada „mówienia wszystkiego”. Dydaktyczne kompetencje wykładowcy oceniane byłyby wtedy tak samo jak dotąd, tyle że na podstawie opinii autentycznych studentów wypowiadających się o autentycznych zajęciach.

Nawet przy coraz radykalniej ograniczanej wolności pracowników nauki wciąż wolności tej zostało wystarczająco dużo, by nie porzucać zupełnie nadziei. Im większy ucisk ze strony władzy, kierujący się zrazu przeciwko wszelkim ,innym” i „niepokornym”, tym większa szansa na radykalny opór. Demokracja to w końcu tylko „projekt w wiecznej budowie, zawsze i z konieczności w pełni niezrealizowany" ${ }^{21}$, wiecznie zagrożony i dlatego wymagający postaw i działań dysydenckich, również, a może przede wszystkim, działań humanistów. „Historia - dopowiada Giroux - pozostaje otwarta. Czas myśleć inaczej, aby działać inaczej, zwłaszcza jeśli jako nauczyciele chcemy wyobrażać sobie inną przyszłość i horyzont możliwości i o nie walczyć”22.

\section{Bibliografia}

Derrida J.: L'université sans condition. Paris 2001.

França J.: Henry Giroux: „Those Arguing that Education Should Be Neutral Are Really Arguing for a Version of Education in Which Nobody Is Accountable". An interview with founder of critical pedagogy Henry Giroux on the meaning of education, suspicions regarding neutrality and on how current uncertainties could be a driving force to rethink and generate new possibilities. CCCB [Centre de Cultura Contemporània de Barcelona]. 2.07.2019. [Online:] http://lab.cccb.org/en/henry-giroux-those-arguing-that

\footnotetext{
${ }^{21}$ H.A. Giroux, S.S. Giroux: Take Back Higher Education..., s. 17.

${ }^{22}$ H.A. Giroux: Thinking Dangerously...
} 
-education-should-be-neutral-are-really-arguing-for-a-version-of -education-in-which-nobody-is-accountable/ [8.06.2020].

Gdula M.: Władza krytyczna i siła wyobraźni. W: Uniwersytet zaangażowany. Przewodnik Krytyki Politycznej. Warszawa 2010, s. 218-226.

Giroux H.A.: The Curse of Totalitarianism and the Challenge of Critical Pedagogy. Truthout. 2.10.2015. [Online:] https://truthout.org/articles/ the-curse-of-totalitarianism-and-the-challenge-of-critical-pedagogy/ [8.06.2020].

Giroux H.A.: Teachers Are Rising Up to Resist Neoliberal Attacks on Education. Truthout. 22.01.2019. [Online:] https://truthout.org/articles/ teachers-are-rising-up-to-resist-neoliberal-attacks-on-education/ [8.06.2020].

Giroux H.A.: Thinking Dangerously: The Role of Higher Education in Authoritarian Times. Truthout. 26.06.2017. [Online:] https://truthout. org/articles/thinking-dangerously-the-role-of-higher-education-in -authoritarian-times/ [8.06.2020].

Giroux H.A.: The Vital Role of Education in Authoritarian Times. Truthout. 11.10.2017. [Online:] https://truthout.org/articles/the-vital-role -of-education-in-a-time-of-tyranny/ [8.06.2020].

Giroux H.A.: Where Is the Outrage? Critical Pedagogy in Dark Times. A public lecture on Thursday, September 24th, 2015. YouTube. 22.10.2015. [Online:] https://www.youtube.com/watch?v=CAxj87RRtsc [8.06.2020].

Giroux H.A., Giroux S.S.: Take Back Higher Education. Race, Youth, and the Crisis of Democracy in the Post-Civil Rights Era. New York-Houndmills 2004.

Janion M.: Studenci to nie jest niższy personel. Z prof. Marią Janion rozmawiaja Kazimiera Szczuka i Sławomir Sierakowski. W: Uniwersytet zaangażowany. Przewodnik Krytyki Politycznej. Warszawa 2010, s. 99-109.

Maliszewski K.: Wióry... Szkic (krypto)terapeutyczny o edukacji wobec zmian współczesnych. „Forum Oświatowe” 2018, nr 1, s. 89-102.

Manifesto for a Post-Critical Pedagogy. Eds. P. Zamojski, N. Hodgson, J. Vlieghe. New York 2018.

Markowski M.P.: Polityka wrażliwości. Wprowadzenie do humanistyki. Kraków 2013.

Sloterdijk P.: Krytyka cynicznego rozumu. Przeł. P. Dehnel. Wrocław 2008.

Zamojski P.: Od demaskacji ku budowaniu. Po-krytyczna perspektywa badań pedagogicznych. „Teraźniejszość - Człowiek - Edukacja” 2014, nr 3, s. 7-22. 
